\title{
内臓肥満型糖尿病患者に対する 防已黄者湯の効果
}

吉田 麻美 ${ }^{122}$ 高松 順太 ${ }^{1)}$ 吉田 滋 ${ }^{1)}$

北岡 治子 ${ }^{1)}$ 増井 義一 ${ }^{1)}$ 大澤 仲昭 ${ }^{1)}$

\section{Effects of Boui-Ougi-To Treatment on Visceral Fat Obesity in Patients with Diabetes Mellitus}

\author{
Mami YOSHIDA $^{12)}$ Junta TAKAMATSU ${ }^{1)}$ Shigeru YOSHIDA ${ }^{1)}$ \\ Haruko KITAOKA $^{1)}$ Yoshikazu MASUI $^{1)}$ Nakaaki OHSAWA ${ }^{1)}$
}

1) M.D.s, First Department of Internal Medicine, Osaka Medical College, Daigaku-cho 2 - 7 Takatsuki-city, Osaka 569, Japan

2 ) M.D., Internal Medicine Aino Hospital, Takada-cho 11-18 Ibaraki-city, Osaka 567, Japan

\begin{abstract}
Nineteen non-insulin dependent diabetes mellitus (NIDDM) patients with obesity were divided into two groups, and a group of eight patients who could try exercise was treated with walking over 160 Calories per day, and a group of eleven patients who could not try exercise was treated with Boui-ougi-to, for six months. Although exercise is known as the treatment of visceral fat obesity, no significant improvement was observed in body mass index, visceral fat / somatic fat (V/S) ratio, blood sugar, serum cholesterol level in the patient group with exercise, whereas in the patient group treated with Boui-ougi-to, serum cholesterol significantly decreased from $197 \pm 31 \mathrm{mg} / \mathrm{dl}$ to $180 \pm 19 \mathrm{mg} / \mathrm{dl}(\mathrm{p}<0.01)$, and $\mathrm{V} / \mathrm{S}$ ratio improved significantly from $0.84 \pm 0.56$ to $0.64 \pm 0.30(\mathrm{p}<0.05)$. These observations suggest that treatment with Bouiougi-to is effective for visceral fat obesity and has potential for the prevention of atherosclerosis.
\end{abstract}

Key words : Boui-ougi-to, diabetes mellitus, visceral fat obesity, atherosclerosis, exercise

Nihon Toyo Igaku Zasshi (Japanese Journal of Oriental Medicine), 49(2), 249-256, 1998

(Accepted ; 24 Mar, 1998)

\section{緒 言}

防已黄者湯の出典は，「金賈要略」であって,
その病湿喝病門に「風湿, 脈浮, 身重く, 汗出で 悪風する者は，防已黄者湯之を主る」，また，水気 病門には, 「風水, 脈浮, 身重く, 汗出で悪風す

\footnotetext{
1) 医，大阪医科大学第一内科，大阪， ₹569-8686 高槻市大学町 2-7

2 ）医，藍野病院内科，大阪，干567-8511 茨木市高田町11-18

〔1998年 3 月24日受理〕
} 
表 1 防已黄者湯投与群および運動療法群における治療前後の比較

\begin{tabular}{|c|c|c|c|c|c|c|c|c|c|c|}
\hline & & 患者数 & $\begin{array}{c}\text { 性 } \\
\text { （男/女） }\end{array}$ & 年齢 & $\begin{array}{c}\mathrm{HbAlc} \\
(\%)\end{array}$ & $\begin{array}{l}\text { T-Cho } \\
\text { (mg/dl) }\end{array}$ & $\begin{array}{c}\mathrm{HDL} \\
(\mathrm{mg} / \mathrm{dl})\end{array}$ & $\begin{array}{c}\mathrm{TG} \\
(\mathrm{mg} / \mathrm{dl})\end{array}$ & $\begin{array}{c}\text { BMI } \\
\left(\mathrm{kg} / \mathrm{m}^{2}\right)\end{array}$ & V/S ratio \\
\hline $\begin{array}{c}\text { 防已黄者湯 } \\
\text { 投与群 }\end{array}$ & $\begin{array}{l}\text { 前 } \\
\text { 後 }\end{array}$ & 11 & $5 / 6$ & $53.3 \pm 13.7$ & $\begin{array}{l}7.5 \pm 2.4 \\
6.8 \pm 1.6\end{array}$ & $\begin{array}{l}197 \pm 31 \\
180 \pm 19^{* *}\end{array}$ & $\begin{array}{l}45 \pm 14 \\
44 \pm 13\end{array}$ & $\begin{array}{l}138 \pm 62 \\
119 \pm 58\end{array}$ & $\begin{array}{l}29 \pm 3 \\
28 \pm 4\end{array}$ & $\begin{array}{l}0.84 \pm 0.30 \\
0.64 \pm 0.30^{*}\end{array}$ \\
\hline 運動療法群 & $\begin{array}{l}\text { 前 } \\
\text { 後 }\end{array}$ & 8 & $3 / 5$ & $50.5 \pm 13.8$ & $\begin{array}{l}6.8 \pm 1.9 \\
6.5 \pm 2.4\end{array}$ & $\begin{array}{l}208 \pm 43 \\
188 \pm 47\end{array}$ & $\begin{array}{l}53 \pm 20 \\
49 \pm 15\end{array}$ & $\begin{array}{l}147 \pm 23 \\
140 \pm 76\end{array}$ & $\begin{array}{l}27 \pm 3 \\
26 \pm 3\end{array}$ & $\begin{array}{l}0.77 \pm 0.26 \\
0.65 \pm 0.30\end{array}$ \\
\hline
\end{tabular}

治療前後の差の検定: ${ }^{*} \mathrm{p}<0.05{ }^{* *} \mathrm{p}<0.01$

腹部 CT 所見

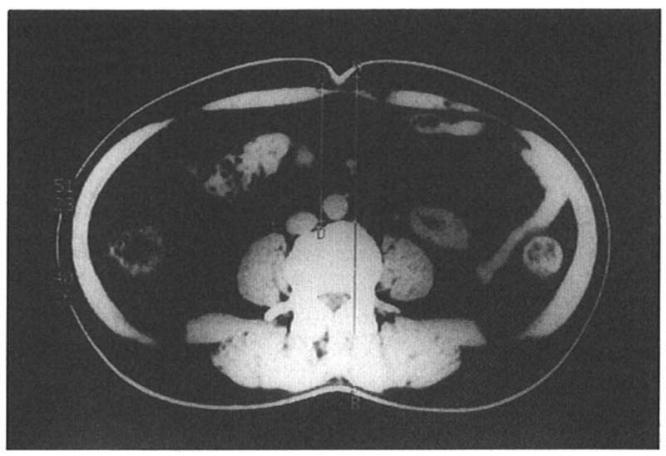

前

\section{BMI}

$\mathrm{HbAic}$

T-Cho

HDL

V/S ratio
26.2

8.1

192

30

2.18
1995. 7.

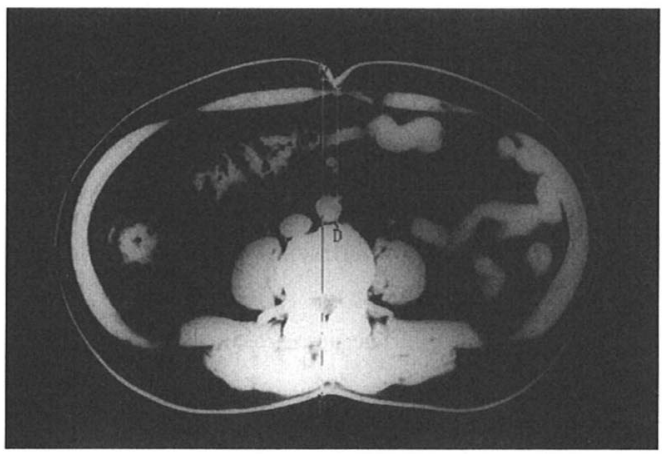

後

25.2

7.8

180

30

図 1 症例の治療経過

る者は，防已黄者湯之を主る」とある1”。本方は，症という症例などである。

表が虚して体表に水毒の多いものを治す方剂で, 色が白く，肉が軟らかく，俗に水ぶとりの体質で, 疲れやすく, 汗の多い傾向の人, また, 下肢に浮 腫が多く，あるいは膝関節が腫脹するものにも用 いる2)。臨床的には，次のような症例に用いる3”。

(1)感冒後皮䖉のしまりが悪く，熱が去らず，悪 風があって自汗が止まらず, 頭痛, 身体疼痛し, 小便不利のもの, (2)腎炎・ネフローゼ・妊娠腎· 陰囊水腫, (3)痽・節・筋炎・下肢骨カリエス・膝 や趾の関節炎・潰瘍・浮腫, (4)肥満症で筋肉軟ら かく, 水ぶとりのもの, (5)皮膚炎·蔚麻疹·多汗

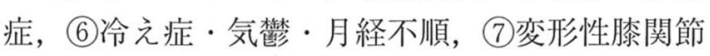

実際の肥満に対する臨床報告としては, 肥満症 例に, 証に従って, 本剤や, 防風通聖散などを投 与した報告がみられる。成田ら ${ }^{4}$ は, 肥満女性68 例中 30 例に本剂を投与し，12週の投与で，30\%以 上の肥満度減少を $8.8 \%, 20 \%$ 以 $30 \%$ 未満を $8.8 \%, 10 \%$ 以上 $20 \%$ 未満を $14.7 \%$ に, 脂質系 には有意な変化はみられなかった。千村ら ${ }^{5)}$ は閉 経期前後の肥満症及び肥満症で高血圧症を伴う患 者33名に, 本剂, 大柴胡湯, 防風通聖散を投与し, 本剂投与群の $66.7 \%$ に体重減少をみたとしている。 肥満についての研究では, 喜多嶋らの食餌性単純 肥満ラットの報告 ${ }^{6}$ があり，水投与群を対照とし 

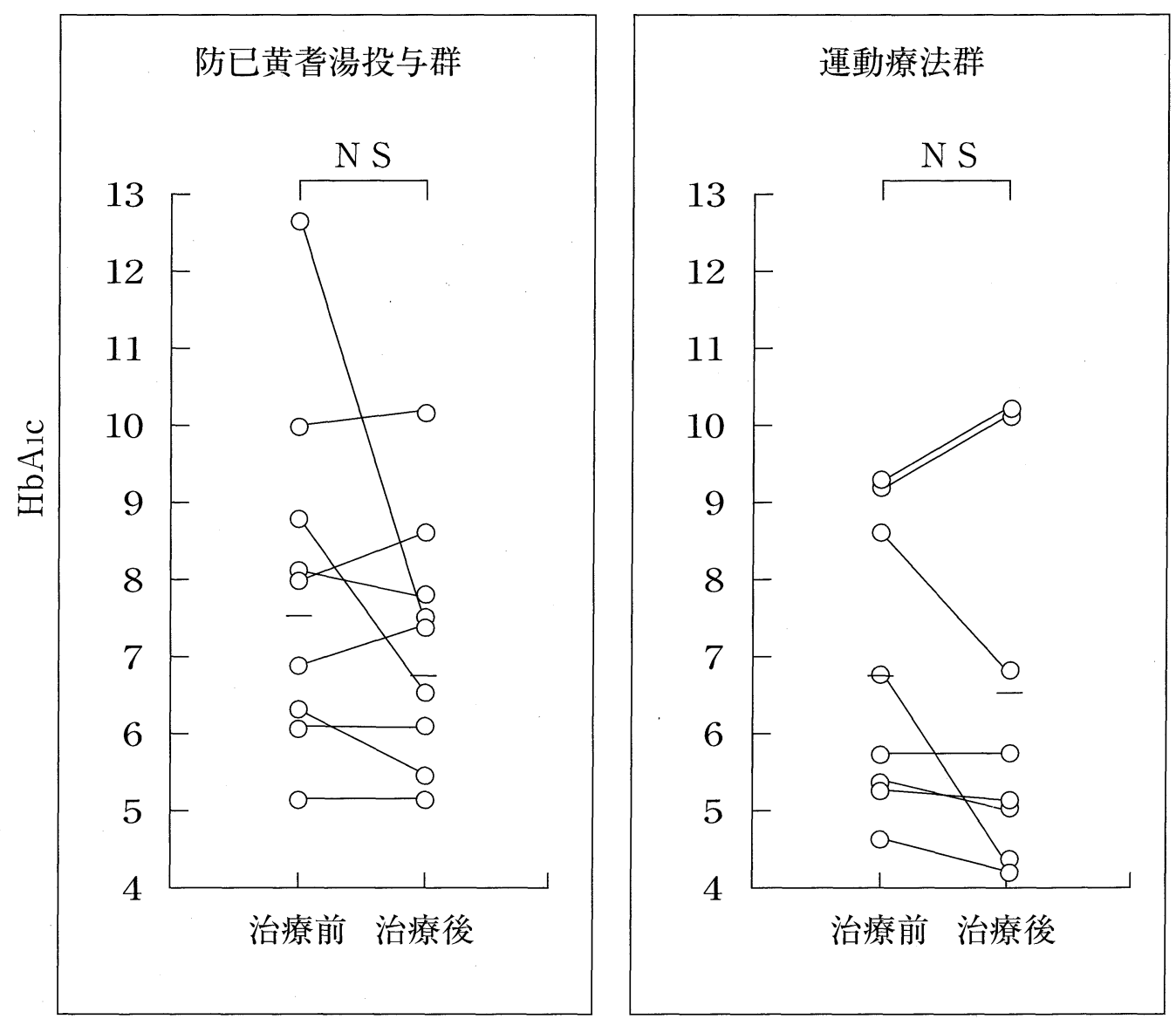

図 $2 \mathrm{HbAlc}$ の変化

て本剂群と防風通聖散群を検討したところ，2剂 群ともに体重減少傾向がみられたが, 本剂群では, 主に尿量の増加によるものと考えられた。

いずれの報告でも，内臓脂肪型肥満に対する本 剂の使用経験の報告は，調べ得た範囲ではみあた らない。一方, 内臓脂肪型肥満の治療法としては, 運動療法が有効とされているが，まだ薬物治療は 確立されていない7)。また実際には，運動療法は 合併症等によって実施困難例も少なくない。我々 は第46回日本東洋医学会学術総会において，10例 の高度肥満糖尿病患者に対し防已黄者湯を投与し， 内臓脂肪が減少し, V/S 比が O. 55士0.06から $0.42 \pm 0.05$ と低下したことを報告した。そこで 運動療法の実施困難な身体状況にある肥満糖尿病 患者に対し，防已黄者湯を投与し，運動療法施行 可能な肥満症例を対照として, 内臓脂肪の変化を
中心に比較検討したので報告する。

\section{対象及び方法}

対象は, 糖尿病外来通院中の肥満を伴う非イン スリン依存性糖尿病（NIDDM）患者19例である。 網膜症や腎症，その他の疾患のため十分な運動療 法の実施困難な身体状況にある症例11例（男性 5

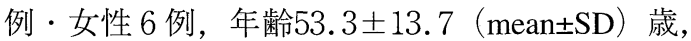
スルフォニルウレア $(\mathrm{SU})$ 㓮投与 5 例・インスリ ン治療 4 例) と, 運動可能な症例 8 例（男性 3 例 - 女性 5 例，年齢50.5 13.8 歳，SU 剂投与 2 例 ・インスリン投与 3 例) に分けた(表 1 )。治療開 始前の諸検査値には，両群間に有意の差を認めな かった。全例食事療法施行の上，運動療法困難群 に，ツムラ防已黄者湯エキス剂 $7.5 \mathrm{~g} /$ 日を 6 力月 間投与し，運動可能群に $160 \mathrm{Cal} /$ 日の有酸素運動 

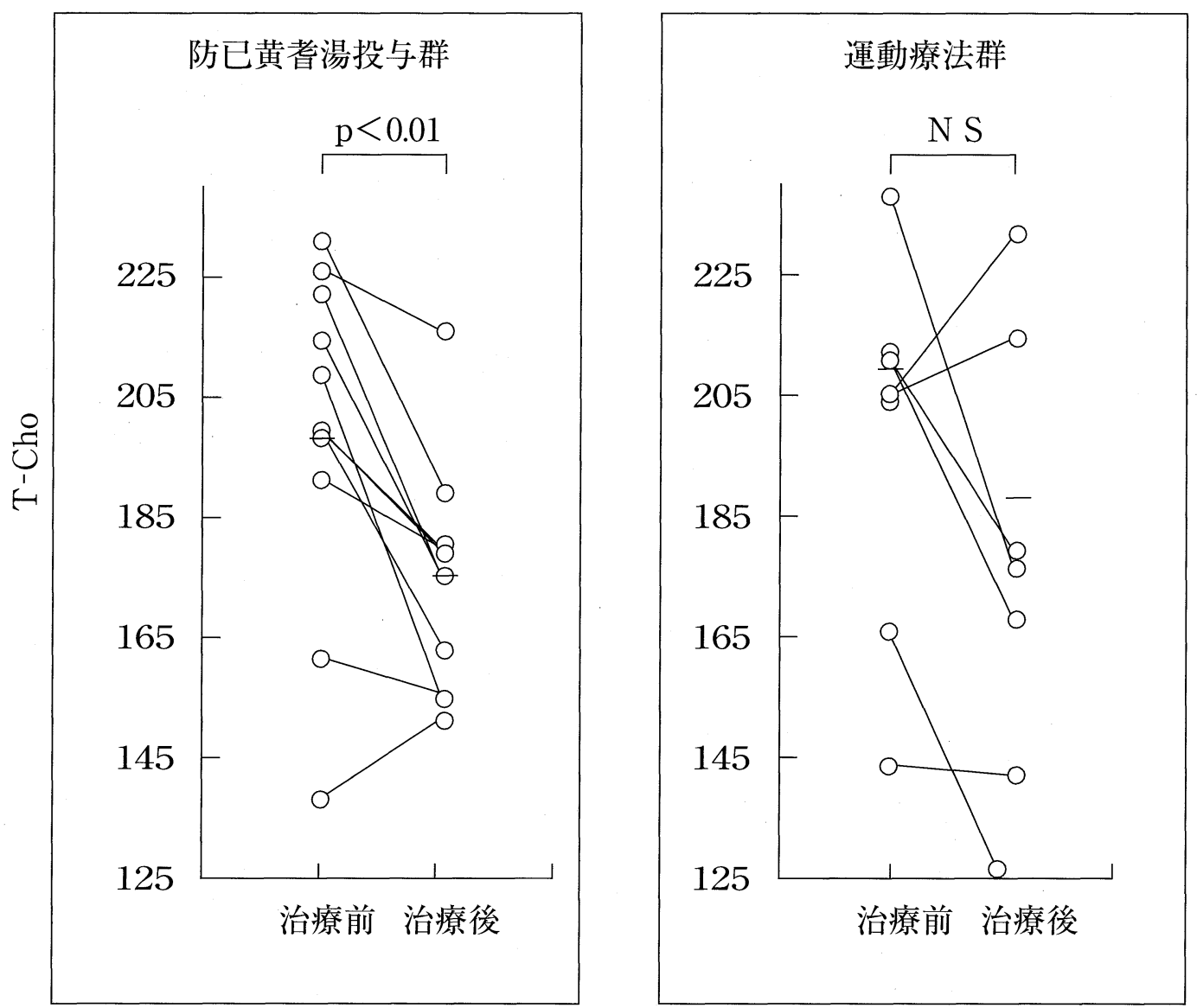

図 3 Total cholesterol の変化

療法 (速歩) を 6 力月間施行, 治療前後で, CT スキャンにて, 臍レベルでの断面像での内臓脂肪 面積 $(\mathrm{V})$ と皮下脂肪面積 $(\mathrm{S})$ を測定し, 内臓脂肪 面積 $(\mathrm{V})$ と皮下脂肪面積 $(\mathrm{S})$ の比（V/S 比）を測 定, 肥満度 ·血糖・脂質の変化を観察した。全例 治療前後で食餌療法は継続して行った。有意差の 検定には，Studentの T検定あるいは Wilcoxonの 検定で検討し， $\mathrm{p}<0.05$ 有意差ありと判定した。

\section{結＼cjkstart果}

\section{1. 症例の呈示}

まず防已黄者湯投与群のうちの代表的な症例を 呈示する。

67歳, 男性

主 訴：めまい感

現病歴: 平成 2 年頃, 健診で糖尿病を指摘され,
他院通院し，SU 剂を処方されていた。しかし同 時期より，めまい・浮遊感が出現。運動療法の徹 底による減量指導も，ウオーキング中のめまいを 恐れて, 運動療法は不可能な状態であった。平成 6 年より当院糖尿病外来へ通院。

身体所見: 身長 $170 \mathrm{~cm}$, 体重 $78 \mathrm{~kg}$, Body mas in$\operatorname{dex}(\mathrm{BMI}) 26.2 \mathrm{~kg} / \mathrm{m}^{2}$, 脈拍 $85 / \mathrm{min}$, 血圧 $120 / 67$ $\mathrm{mmHg}$ ，胸腹部打聴診所見異常なし。

検査成績: 検尿; 尿糖 $(+)$, 血液一般異常なし, 血液生化学; FBS 123mg/dl, T-Cho 192mg/dl, HDL $30 \mathrm{mg} / \mathrm{dl}$, TG106mg/dl, HbAic 8.1g/dl. 胸部 X-p ; 異常なし, ECG; 異常なし, 腹部エコー; 脂肪, 肝腹部 CT ; 内臓脂肪型肥満, V/S 比 : 2.18.

漢方医学的所見：疲れやすい，汗をかきやすい。 顔面は紅潮，四肢の冷えはない。小便の量と回数 は正常。便通も異常なし。舌は正常紅舌で湿潤し 

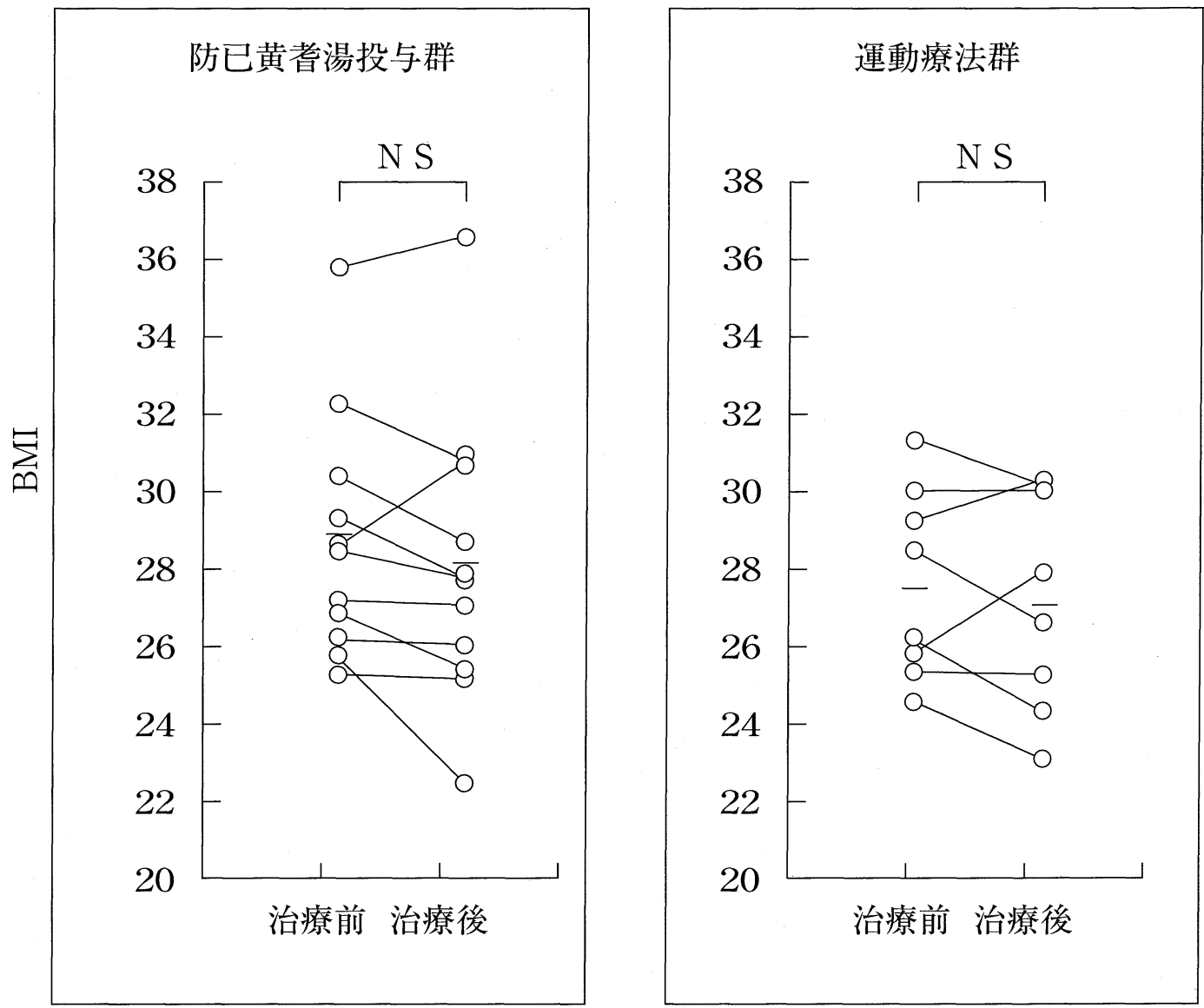

図 4 BMI の変化

たごく薄い白苔を認める。脈はやや浮でわずかに 虚証。腹診では腹力やや軟弱で軽度膨隆認める。

経過: 高度の内臓脂肪蓄積に対し, ツムラ防已 黄者湯 $7.5 \mathrm{~g} /$ day を投与。 6 力月にて BMI は 25.2 $\mathrm{kg} / \mathrm{m}^{2}$ と軽度低下, $\mathrm{V} / \mathrm{S}$ 比は 2.18 か 1.42 と低 下した。(図 1 )

\section{2 群間の比較}

治療前後の諸検査值の変化を表 1 及び図 2 から 図 5 に示した。

血糖コントロール状態（HbAic）は，防已黄者 湯投与群 (以下 A 群) - 運動療法群 (以下 B 群) ともに改善傾向を示すも有意差はみられなかった

(図 2 )。血清コレステロール值は A 群で197士31 $\mathrm{mg} / \mathrm{dl}$ から $180 \pm 19 \mathrm{mg} / \mathrm{dl}(\mathrm{p}<0.01)$ と有意に改 善， $\mathrm{B}$ 群では改善傾向を示すも有意差はみられな かった（図３）。HDL,TGは, 両群とも改善傾向
を示すも有意な変化はみられなかった。肥満度 (Body Mass Index : BMI) は, 両群とも治療前後 で有意な改善は認めなかった（図 4 )。V/S 比は， $\mathrm{A}$ 群で $0.84 \pm 0.56$ から $0.64 \pm 0.30(\mathrm{p}<0.05)$ と有意に改善（図 5 )。証に関しては，1例をの ぞいてすべて中間証から虚証であったが，この漢 方医学的診察上は実証で防已黄者湯証ではないと 思われた症例でも V/S 比低下をみた。一方 B 群 では, 治療前後でV/S 比は0.77土0.26から $0.65 \pm 0.30$ と低下傾向を示したが，有意差はみ られなかった。また，副作用は一例も認めなかっ た。

\section{考 察}

内藏脂肪型肥満8) (Visceral fat obesity) は，体 内の脂肪蓄積の分布が皮下ではなく, 腹腔内（腸 

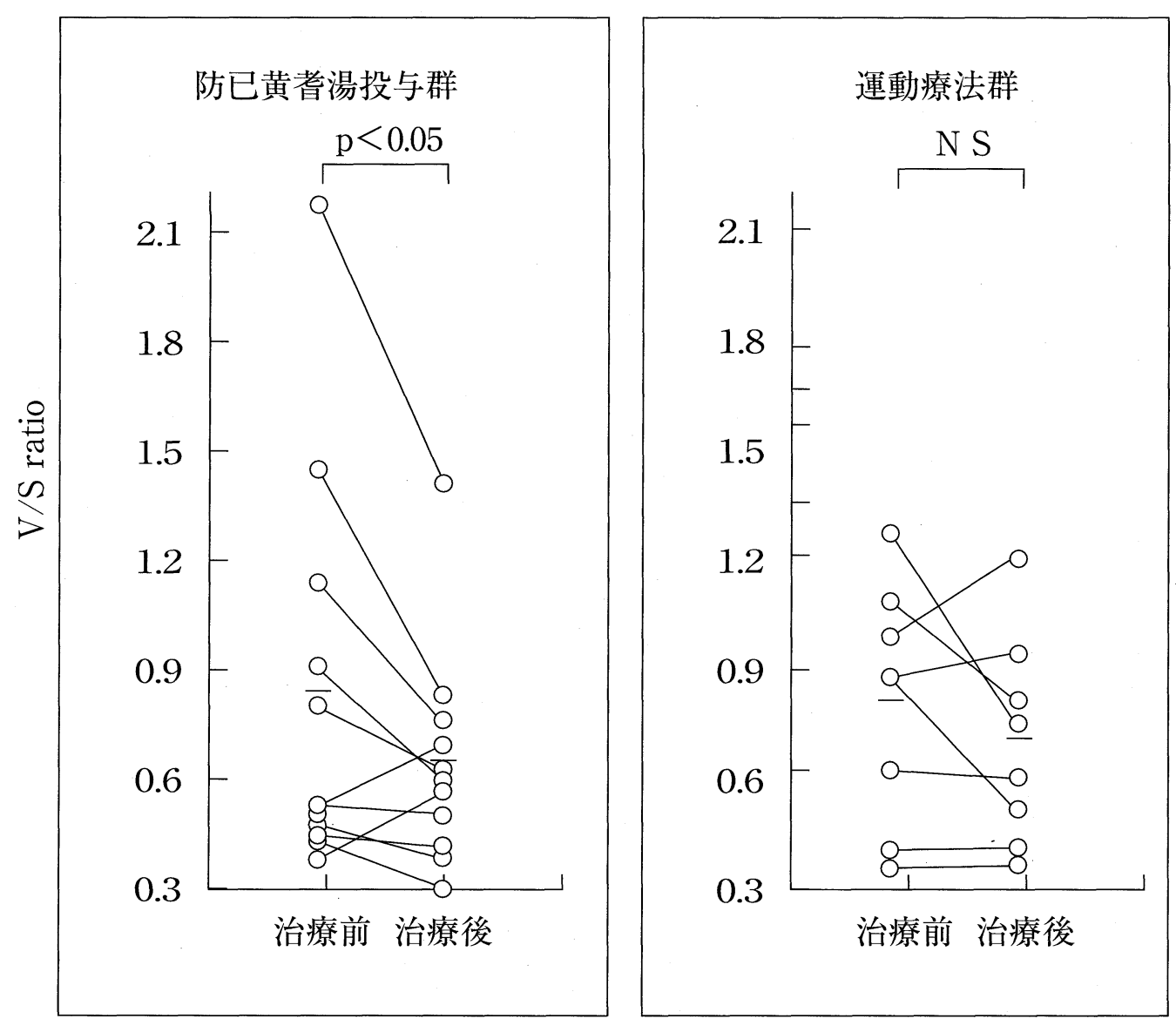

図 $5 \mathrm{~V} / \mathrm{S}$ 比の変化

間膜や大網）に著明なタイプであり，インスリン 抵抗性が強く, 動脈硬化のリスクファクターとし て注目されている。内臓脂肪は, 脂肪合成および 分解活性がともに高い組織で，このため過剩に生 じた遊離脂肪酸（FFA）が，門脈より直接肝蔵へ 流入するため，肝でのインスリン感受性を低下さ せたり，クリアランスを抑制するなど，インスリ ン抵抗性を増悪させ，糖代謝異常につながる。ま た肝臓での FFA 過剩は, 肝での脂肪合成の基質 増加をきたし, 高脂血症増悪につながる9)。そこ で, 内臓脂肪の蓄積を基盤に, 而糖能異常・高脂 血症・高血圧を併せ持つ, multiple risk clustering syndrome を, 「内臓脂肪症候群」と称し, 本邦 における動脈硬化性疾患の発症に重要であると提 唱されている9)。脂肪の分析は, CTスキャンに て, 臍レベルでの断面像での内臓脂肪面積 $(\mathrm{V})$ と
皮下脂肪面積 $(S)$ の測定を行い, 肥満者ではV/S 比が動脈硬化性疾患の合併と最も強く関連するこ とが明らかになっており, V/S 比 ミ0.4を内臓脂 肪型肥満と判定されている 動脈硬化はV/S 比より, 内臓脂肪面積とより強 い関連があるとされている。

防已黄耆湯は, 防已 ·黄者 · 蒼术 · 大雵 $\cdot$ 甘草 - 生姜の 6 種類の生薬から構成されており, 防已 ・黄者が主薬である。防已の主要成分としては, sinomenine ${ }^{10)}$, tetrandrine $\mathrm{e}^{11)}$ な゙のアルカロイドが 知られて抢り, 抗アレルギー作用 ${ }^{10)}$ や抗炎症作用 ${ }^{11}$, 鎮痛作用 ${ }^{12}$ 等が認められている。また黄者は，血 圧降下作用 ${ }^{13)}$ ・末梢血管搪張作用 ${ }^{14)}$ ・抗アレル ギー作用 ${ }^{15)}$ ・利尿作用 ${ }^{16)}$ な゙が知られている。い ずれの生薬にも, 抗肥満作用は, 明らかにはされ ていない。しかし, 黄者には, in vivoにて血中 
cAMP 増加作用 ${ }^{17)}$ や再生肝中の DNA 合成促進作 用 ${ }^{17)}$ ，また血清と肝臓の蛋白合成促進作用 ${ }^{18}$ など の細胞の代謝賦活作用が報告されており，内臟脂 肪肥満の改善に関与しているかもしれない。一方 運動療法では，ラットを用いた実験から，内臓脂 肪が特異的に減少することが証明されている

今回の我々の検討の結果, 防已黄者湯は, 内臓 脂肪型肥満，さらに脂質代謝に対し，運動療法以 上の効果を発揮することが示された。今回の結果 では，運動療法群で，有意な内臓脂肪減少が得ら れなかったが，症例数の不足で明確なことはいえ ない。また，防已黄者湯投与群は，11例中10例が 本証であったと考えられるが，本剤の適応する病 態は運動不足で多いともいわれており ${ }^{20)}$ ，さらに 糖尿病で運動困難を引き起こす合併症を持つ病態 は虚証が多いと考えられ，運動療法施行困難な内 臓肥満型糖尿病は防已黄者湯証に合致することが 多いと思われる。このように防已黄耆湯によって, 内臓脂肪のみならず，脂質・糖質改善をみること は，動脈硬化進展を予防する可能性を示唆してお り，今後長期にわたって経過観察する必要がある。

\section{結＼cjkstart論}

1 . 運動療法施行困難な内臟肥満型糖尿病患者 に，防已黄者湯を 6 力月投与し，有意な内蔵脂肪 減少，コレステロール低下，また血糖改善傾向を みた。この結果は, 内臓脂肪型肥満に有効とされ ている運動療法施行群と比べても明らかであった。

2.内臓肥満型糖尿病患者で, 運動療法困難な 患者には，防已黄者湯を試みるとよいと思われる。

3．防已黄者湯は，内臓脂肪型肥満さらに動脈 硬化予防に対し有用である可能性が示唆された。

\section{文 献}

1 ）大塚敬節：金買要略講話，59-60，356，創元社, 大阪 (1992)

2 ）大塚敬節，他：漢方診療医典，418, 南山堂, 東京 (1990)

3 ）矢数道明：臨床応用 漢方処方解説，548-554, 創元社，大阪 (1992)

4 ）成田収, 他：肥満症に対する漢方療法の効果,
産科と婦人科， 2， 123-129（1983）

5 ）千村哲郎：肥満・高脂血症に対する漢方製剤の 臨床的検討, 産婦人科の世界, 45, 339-346 (1993)

6 ) 喜多嶋修也, 他: 肥満症に対する防風通聖散, 防已黄耆湯の影響, 日本東洋医学雑誌, $43(5)$, 63 (1993)

7 ) Fujioka $S$, et al : Treaatment of visceral fat obesity. Int. J. Obesity, 15, 59-65 (1991)

8 ) Matszawa Y, et al. : A novel classification of obesities-visceral fat obesity and subcutaneous fat obesity. Recent Advances in Obesity Research, 92-96 V. John Libbey, London (1987)

9 ) 中村正, 他：新しい動脈硬化リスクファク 夕一：内藏脂肪症候群, Pharma Medica, 12 (5), 57-61 (1994)

10) Mayeda $\mathrm{H}:$ The release of histamine by sinomenine. Jap. J. Pharmacol., 3, 62-72, (1953)

11）山原條二, 他：防已科植物アルカロイドの薬理 作用 (その 1) tetrandrine の薬理作用, 生薬学 雑誌， 28(2)，83-95（1974）

12）大野博之：Histamine 及び Histamine 遊離物質を 反復投与したマウスにおける鎮痛性薬物の作用, 日薬理誌，55，109-125（1959）

13）有澤宗久, 他：天然物のアンジオテンシン変換 酵素(ACE)阻害活性の研究, 生薬学雑誌, 39(3), 246-249 (1985)

14）寺田文次郎, 他：漢薬黄耆の薬理作用について, 日薬物誌，18，40（1934）

15）泰克滔，他：生薬の抗アレルギー作用について, 日本薬学会102年会講演要旨集，587（1982）

16）黄厚聘, 他: 黄耆の利尿と降圧作用, 薬学学報, 12(5), 319-324（1965）

17）張銀嫌, 他：黄者の血漿 cAMP 及び再生肝 DNA 合成に対する作用，薬学学報，19(8)，619-621 (1984)

18) Shen M. The contribution of traditional chinese medicine to modern pharmacology, TIPS, 4, 496 (1983)

19）下村伊一郎，他：内臟脂肪（内臟脂肪症候群） に対する運 動療 法の意義一分子生物学的観点 
からー, 臨床スポーツ医学, 11(3), 265-270

(1994)
20）寺澤捷年：症例から学ぶ和漢診療学, 261 , 医 学書院, 東京 (1990)

要旨 肥满を伴うインスリン非依存性糖尿病（NIDDM）患者19例に対し, 運動療法が可能 な 9 例では, 160 Calorie/日の有酸素運動（速歩）療法を 6 力月間施行，実施困難な身体状況 にある11例には，防已黄者湯を 6 カ月間投与した。運動療法は内臓脂肪型肥満に有効とされて いるが, 運動療法群では, 治療前後で, CT スキャンを用い測定した内臓脂肪面積と皮下脂肪 面積の比（V/S 比）が $0.77 \pm 0.26$ から $0.65 \pm 0.30$ へ低下したが，肥満度及び血糖，脂質に ついても有意な改善をみなかった。一方，防已黄者湯投与群では，血清コレステロール值が 197 $\pm 31 \mathrm{mg} / \mathrm{dl}$ から $180 \pm 19 \mathrm{mg} / \mathrm{dl}(\mathrm{p}<0.01)$ ，またV/S 比が $0.84 \pm 0.56$ から $0.64 \pm 0.30 （ \mathrm{p}$ $<0.05 ） へ と$ 有意に改善，血糖值も改善傾向であった。今回の結果から，防已黄者湯は内臓 脂肪型肥満さらに動脈硬化予防に対し有用である可能性が示唆された。

キーワード：防已黄者湯・糖尿病 ·内臓脂肪型肥満・動脈硬化・運動療法 